\title{
Severe post-partum autoimmune hypothyroidism associated with a novel loss-of-function mutation in intracellular domain of human thyrotropin receptor
}

\section{Ostra poporodowa autoimmunologiczna niedoczynność tarczycy związana z nowa mutacją utraty funkcji w wewnątrzkomórkowej domenie ludzkiego receptora TSH}

\author{
Arindam Bose ${ }^{1}$, Norman Sharma², Nanda Hemvani ${ }^{1}$, Dhananjay S. Chitnis ${ }^{1}$ \\ ${ }^{1}$ Department of Microbiology, Immunology, and Molecular Biology, Choithram Hospital and Research Centre, Indore, India \\ Head of the Department: Prof. Dhananjay S. Chitnis PhD \\ 2Department of Endocrinology and Metabolism, Choithram Hospital and Research Centre, Indore, India \\ Head of the Department: Dr. Norman Sharma MD
}

Key words: hypothyroidism, thyroid stimulating hormone receptor, mutation.

Słowa kluczowe: niedoczynność tarczycy, receptor TSH, mutacja.

\begin{abstract}
Several loss-of-function TSHR gene mutations have been reported previously. In the present study, a mutation in exon 10 of the TSHR gene was studied. A 35-year-old mother of two children attended our hospital with symptoms of hypothyroidism after her second delivery. She had elevated levels of thyroid hormones including both the thyroid antibodies and those treated with L-thyroxine. In the present study, exon 10 of the TSHR gene of the patient was studied. Sequencing of exon 10 revealed a $\mathrm{G}$ to $\mathrm{T}$ transversion, resulting in a loss of function mutation changing glutamic acid 757 to stop codon, (E757Stop) in the intracellular domain of TSH receptor and also $\mathrm{C}$ to $\mathrm{T}$ transition, leading to no change in amino acid sequence (glycine to glycine at 753 amino acid position). We report a novel sporadic loss of function mutation in TSHR protein at codon 757 (E757Stop).
\end{abstract}

\section{Streszczenie}

Publikacje na temat mutacji utraty funkcji genu TSHR pojawiały się już wcześniej. W prezentowanej pracy zbadano mutację w pozycji eksonu 10 genu TSHR. Do szpitala zgłosiła się 35-letnia matka dwojga dzieci z objawami niedoczynności tarczycy po drugim porodzie. Miała podwyższony poziom hormonów tarczycy, w tym zarówno przeciwciał przeciwtarczycowych, jak i L-tyroksyny. W pracy przestudiowano ekson 10 genu TSHR pacjentki. Przy sekwencjonowaniu eksonu 10 odkryto transwersję G do T, czego skutkiem jest mutacja utraty funkcji zmieniająca kwas glutaminowy 757 na kodon stop (E757Stop) w wewnątrzkomórkowej domenie receptora TSH, a także przejście C do T, nieprowadzące do żadnej zmiany w sekwencji aminokwasu glutaminowego (glycine to glycine w pozycji aminokwasu 753). Przedstawiamy raport na temat nowej sporadycznej mutacji utraty funkcji w białku TSHR w pozycji kodonu 757 (E757Stop).

\section{Introduction}

The physiological action of thyroid stimulating hormone (TSH) is mediated by a G protein coupled "seven trans-membrane domain receptor", the thyroid stimulating hormone receptor (TSHR) [1]. This interaction leads to activation of second messenger pathways involving cAMP, inositol 1, 4, 5-triphosphate, and diacylglycerol (DAG), leading to the production and secretion of $\mathrm{T}_{4}$ and $\mathrm{T}_{3}$ [2]. The extracellular part of this receptor is involved in the binding of TSH, and the trans-membrane and intracellular domain has effector properties triggering $G$ protein ac- tivation [3]. The gene organisation reflects these dual functions because a single exon (exon 10) encodes the trans-membrane and intracellular domain, whereas the extracellular domain is encoded by the remaining nine exons [4].

Since the first report of Congenital Hypothyroidism caused by a TSHR mutation, several cases of lossfunction mutations of TSHR have been reported. Most of the mutations are missense mutations, but deletions and insertions have been identified as well [5].

Upon binding of TSH to its receptor, the main pathway of the signal transduction involves the activation of the adenylate cyclase through $G$ protein 
coupling and the intracellular production of cAMP [6]. Because the TSHR has a central role in the control of human thyroid follicular cell proliferation and function, it is expected that its deregulation would lead to pathological processes.

In a familial study conducted on a Caucasian population, a missense mutation (W546X mutation) in exon 10 was detected in approximately 1 in 180 individuals and it was concluded that it could be a major contributor to hypothyroidism in the Welsh population [7]. The mechanism leading to loss-of-function mutations of TSHR includes abnormal binding affinity, abnormal receptor synthesis, accelerated degradation, defective receptor targeting to the cell membrane, and abnormal signal transduction [8]. Mutations may exert their activity by causing protein misfolding, misassembly or aberrant oligomerisation. Loss-of-function mutations are located all along the TSHR [9].

In India, genetic study on hypothyroidism is scarce, especially on TSHR. Here we report a novel mutation in a post-partum hypothyroid patient at our end.

\section{Case report}

The study was conducted in accordance with the Helsinki Declaration [10]. Written informed consent for molecular studies was obtained from the patient. The study was approved by the Choithram Hospital and Research Centre Ethics Committee (DCGI registered ethics committee as per guidelines of Indian Council of Medical Research).

\section{Patient's background}

The patient is a 35-year-old mother of two with no family history of thyroid disorders or any other endocrine diseases.

\section{During pregnancy}

During both pregnancies, she did not manifest any symptoms of hypothyroidism. All the haematological biochemical and endocrinological parameters including thyroid profiles were within normal range during both pregnancies. Both children were born by normal delivery without any complications.

\section{Post pregnancy}

\section{At the time of diagnosis of hypothyroidism}

The patient arrived at our hospital outpatient department 6 months after she delivered her second child. She complained of weight gain, numbness in the hand, lethargy, and hair loss. Swelling on the face and trunk was also observed. Her height and weight was measured and the body mass index (BMI) was calculated. At the time of diagnosis her BMI was above normal (Table 1). The haematological, biochemical, and endocrinological parameters were measured using Sysmax XT-1800 (based on DC method with Hydrodynamic Focusing, Flow Cytometry method, and SLS-Haemoglobin method), Cobus C311 (based on CHOD-PAP method for total Cholesterol and Roche III gen method for low-density lipoprotein (LDL) and high-density lipoprotein (HDL) cholesterol), and Abbott Architect i1000SR (based on Chemiluminescent Microparticle Immunoassay for thyroid hormone profile and thyroid antibodies estimation), respectively. At the time of diagnosis the estimated values of thyroid hormones in serum (Table 1) indicated that the patient was suffering from hypothyroidism. Marked elevation of both the thyroid antibodies (thyroglobulin and thyroid peroxidase antibodies) in the serum (Table 1) suggested autoimmune hypothyroidism. Borderline elevations of serum lipids were also observed, and the haematological values were within normal range (Table 1). It was recommended that the patient be treated with a dose of $100 \mu \mathrm{g}$ L-thyroxine per day.

\section{Patient follow-up}

After 15 days follow-up, symptomatic improvement was seen in the patient, and reassessment of her serum TSH and serum cholesterols every 6 months was advised. During the first 6-month follow-up the serum TSH value was still elevated and the serum cholesterols were within normal range (Table 1). The dose of L-thyroxine was increased to $125 \mu \mathrm{g}$ per day. The thyroid hormone levels were within normal range in the last two 6-month follow-ups of the patient (Table 1).

\section{Molecular biological findings of the patient}

\section{Methodology}

In the present study, exon 10 of the TSHR gene of the patient, her mother, and her brother was studied. DNA was isolated from whole blood by using a DNA extraction Kit (DNA extraction Kit, Qiagen, USA). Extracted DNA was amplified by polymerase chain reaction (PCR) method. Due to a large sequence of exon 10 of the TSHR gene, two sets of DNA primers (each set of primers consisted of one forward and one reversed sequence) were used to amplify the DNA products in two parts (part I and part II) (Table 2) [11]. The PCR products were analyzed by running a $1 \%$ agarose gel, stained with ethidium bromide. The amplified products were purified by Qiagen Gel Extraction Kit and were sequenced using BigDye Terminator Cycle Sequencing Ready Reaction Kit (Applied Biosystems, Foster City, CA, USA) and the results in the form of a biogram were analysed using the computer software BioEdit. Part I and Part II sequences of exon 10 were submitted to GenBank and the provided accession numbers were KT240093 and KT318753, respectively, for the patient, KT318754 and KT318755 for her mother, and KT318756 and KT318757 for her brother. 
Table 1. The physiological parameters of the patient during diagnosis and follow-up

\begin{tabular}{|c|c|c|c|c|c|}
\hline Parameters & Normal range & $\begin{array}{l}\text { At the time } \\
\text { of diagnosis }\end{array}$ & $\begin{array}{l}6 \text { monthly } \\
\text { follow-up }\end{array}$ & $\begin{array}{c}\text { Yearly } \\
\text { follow-up }\end{array}$ & $\begin{array}{l}1.5 \text { yearly } \\
\text { follow-up }\end{array}$ \\
\hline \multicolumn{6}{|l|}{ Physical parameters: } \\
\hline Height $[\mathrm{cm}]$ & NA & 154 & 154 & 154 & 154 \\
\hline Weight [kg] & $43.87-59.05$ & 68.3 & 72.1 & 76.3 & 82.1 \\
\hline BMI $\left[\mathrm{kg} / \mathrm{m}^{2}\right]$ & $18.5-24.9$ & 28.8 & 30.4 & 32.2 & 35 \\
\hline \multicolumn{6}{|c|}{ Endocrinological, biochemical, and haematological parameters: } \\
\hline Total $\mathrm{T}_{3}[\mathrm{ng} / \mathrm{dl}]$ & 60-181 & 53.8 & - & - & 93.2 \\
\hline 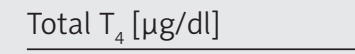 & $4.5-12.6$ & 2.3 & - & - & 8.6 \\
\hline $\mathrm{TSH}[\mu \mathrm{lu} / \mathrm{ml}]$ & $0.35-4.94$ & 52.0 & 8.7 & 1.2 & 0.7 \\
\hline Free $\mathrm{T}_{4}[\mathrm{ng} / \mathrm{dl}]$ & $0.7-1.48$ & 0.53 & - & - & 1.43 \\
\hline Anti Tg Ab [IU/ml] & $\leq 4.11$ & $\geq 1000$ & - & - & 56.88 \\
\hline Anti TPO Ab [IU/ml] & $\leq 5.61$ & $\geq 1000$ & - & - & 658.93 \\
\hline Total cholesterol [mg/dl] & $120-220$ & 234 & 216 & - & 220 \\
\hline LDL cholesterol [mg/dl] & $80-130$ & 133 & 129 & - & 126 \\
\hline HDL cholesterol [mg/dl] & $40-80$ & 40 & 42 & - & 42 \\
\hline $\mathrm{Hb}$ [gm\%] & $11.5-16$ & 11.0 & - & - & 12.9 \\
\hline RBC [million/mm $\left.{ }^{3}\right]$ & $3.8-4.8$ & 4.4 & - & - & 4.97 \\
\hline WBC $\left[\mathrm{mm}^{3}\right]$ & $4,000-10,000$ & 10,000 & - & - & 7,100 \\
\hline Platelets [Lacs/mm³] & $1.5-4.5$ & 2.6 & - & - & 3.69 \\
\hline PCV (\%) & $36-46$ & 34 & - & - & 39.4 \\
\hline $\mathrm{MCHC}(\%)$ & $28-40$ & 32.7 & - & - & 32.7 \\
\hline \multicolumn{6}{|c|}{ Dose of L-thyroxine $[\mu \mathrm{g} / \mathrm{day}]$ : } \\
\hline NA & NA & 0.0 & 100.0 & 125.0 & 125.0 \\
\hline
\end{tabular}

Table 2. Working DNA primer sequence

\begin{tabular}{|lccc|}
\hline Name of exon & Primer sequence & Ta $\left[{ }^{\circ} \mathrm{C}\right]$ & PCR product size [bp] \\
Exon 10 (part I) & F - ACT GTC TTT GCA AGC GAG TT & 50 & 875 \\
Exon 10 (part II) & F - GTG TCA TGG GAT TGG AAT GC & & 868 \\
& R - GTC CAC TGA CTC TTT TCT GT & 50 & \\
\hline
\end{tabular}

$T a(T m-5)$ - Annealing temperature, $F-$ forward sequence $\left(5^{\prime} \rightarrow 3^{\prime}\right), R$-reversed sequence $\left(3^{\prime} \rightarrow 5^{\prime}\right)$, bp - base pair.

\section{Results}

Sequencing of exon 10 of the TSHR gene in the patient revealed a $\mathrm{G}$ to $\mathrm{T}$ transversion at nucleotide position 177035 (emb|AL136040.5|), predicted to result in a loss of function mutation changing glutamic acid 757 to stop codon, (E757Stop) in the intracellular domain of $\mathrm{TSH}$ receptor and also $\mathrm{C}$ to $\mathrm{T}$ (Transition) silent mutation at 177025 nucleotide position (emb|AL136040.5|), which leads to no change in amino acid sequence (glycine to glycine at 753 amino acid position).

No mutational changes were observed in the gene analysis of the mother and brother of the patient, and their thyroid hormone parameters including thyroid antibodies were within normal range.

\section{Discussion}

Indore is located in the central part of India. Although this is an iodine sufficient region, previous studies reported that the incidence of hypothyroidism including subclinical and autoimmune thyroiditis is very high in this region [12]. Post-partum thyroiditis (PPT) appears to be identical to a transient form of autoimmune thyroiditis, and by the presence of thyroid antibodies is considered secondary to an 
exacerbated autoimmune response following the loss of placenta-induced immune suppression [13]. Postpartum thyroiditis may not always be transient and can also appear as a slow or fast evolution of permanent thyroid failure.

Loss-of-function mutations in the TSH receptor gene (TSHR) lead to a resistant TSH (RTSH) syndrome, presenting with either congenital hypothyroidism $(\mathrm{CH})$ or subclinical hypothyroidism [14]. But one can speculate that it may appear as PPT.

In the present study we report a novel sporadic loss of function mutation of a $\mathrm{G}$ to $\mathrm{T}$ transversion identified in exon 10 of the TSHR gene, which leads to the glutamic acid to stop codon (E757Stop) change at codon 757 in amino acid sequence of TSHR protein. Along with the novel loss-of-function mutation, a $\mathrm{C}$ to $\mathrm{T}$ (transition) silent mutation was also identified.

Most of the published articles have used sequencing of PCR-amplified fragments of exon 10 of the TSHR gene because this single exon encodes the transmembrane domain. The rationale for this approach was that the likelihood of finding activating mutations in this domain was high because it is involved in signal transduction, as demonstrated by studies with the $\alpha 1$-adrenergic receptor [15]. The wild type and the mutated receptor gene were then transiently transfected in eukaryotic cells to confirm that the mutation conferred constitutive activation.

The mechanism leading to loss-of-function mutation of TSHR includes abnormal binding affinity, abnormal receptor synthesis, accelerated degradation, defective receptor targeting to the cell membrane, and abnormal signal transduction [8]. The TSHR gene has been defined as highly mutable [16]. The inactivating mutations of TSHR can account for several cases of non-autoimmune subclinical hypothyroidism, in particular those arising in familial settings. The cases detected in neonatal TSH screening were treated lifelong because hyperthyrotropinaemia is not transitory [17]. Cangul et al. utilised genetic linkage analysis and direct sequencing to detect a homozygous nonsense mutation (R609X) in the case of congenital hypothyroidism. They reported for the first time with a R609X mutation in a familial case [18].

A T607I sporadic heterozygous mutation in TSHR gene associated with partial TSH resistance has been reported [19]. Despite several reports of patients affected by TSHR mutations, there are limited data on the long-term outcome of this condition. Sometimes TSHR mutations do not develop hypothyroidism; in contrast, in autoimmune thyroid disease (AITD), overt hypothyroidism commonly develops over the years. In a cohort study of affected family members, cross-sectional analysis showed neither a decrease nor an increase in TSH levels with age, suggesting stable compensated RTSH with an appropriately adjusted set point of pituitary-thyroid feedback [20]. In contrast to subclinical hypothyroidism in the context of AITD, the thyroidal compensation in mild to moderate RTSH is expected to be clinically stable with no progression toward true hypothyroidism or spontaneous regression toward normal TSH levels. In contrast, development of overt hypothyroidism at the age of 15 years was shown in a patient homozygous for the $\mathrm{R} 540 \mathrm{H}$ mutation presenting with compensated hypothyroidism in infancy, but not in an additional four subjects with the same genotype after long-term follow-up [21].

A mutation in the TSHR gene is very rare. To our best knowledge, we are reporting a novel loss of function mutation in TSHR protein at codon 757 (E757Stop), which has not been reported previously. Further study is needed to enumerate the prevalence and frequency of the incidence of the reported mutation in the population, especially in the Indian population.

\section{Acknowledgments}

We would like to express our gratitude to the management of Choithram Hospital and Research Centre, Indore, India for providing infrastructural support. We also express our gratitude to the staff members of the Department of Pathology of Choithram Hospital and Research Centre, Indore.

\section{Conflict of interest}

The authors declare no conflict of interest.

\section{References}

1. Parmentier M, Libert F, Maenhaut C, Lefort A, Gerard C, Perret J, Van Sande J, Dumont JE, Vassart G. Molecular cloning of the thyrotropin receptor. Science 1989; 246: 1620-2.

2. Jackson IM. Thyrotropin-releasing hormone. N Engl J Med 1982; 306: 145-55.

3. Vassart G, Dumont JE. The thyrotropin receptor and the regulation of thyrocyte function and growth. Endocr Rev 1992; 13: 596-611.

4. Gross B, Misrahi M, Sar S, Milgrom E. Composite structure of the human thyrotropin receptor gene. Biochem Biophys Res Commun 1991; 177: 679-87.

5. Sriphrapradang C, Tenenbaum-Rakover Y, Weiss M, Barkoff MS, Admoni O, Kawthar D, Caltabiano G, Pardo L, Dumitrescu AM, Refetoff S. The coexistence of a novel inactivating mutant thyrotropin receptor allele with two thyroid peroxidase mutations: a genotype-phenotype correlation. J Clin Endocrinol Metab 2011; 96: E1001-6.

6. Wess J. G-protein-coupled receptors: molecular mechanisms involved in receptor activation and selectivity of G-protein recognition. FASEB J 1997; 11: 346-54.

7. Jordan N, Williams N, Gregory JW, Evans C, Owen M, Ludgate M. The W546X mutation of the thyrotropin receptor gene: potential major contributor to thyroid dysfunction in a Caucasian population. J Clin Endocrinol Metab 2003; 88: 1002-5.

8. Tao YX. Inactivating mutations of G protein-coupled receptors and diseases: structure- function insights and therapeutic implications. Pharmacol Therap 2006; 111: 949-73. 
9. Biebermann H, Winkler F, Kleinau G. Genetic defects, thyroid growth and malfunctions of the TSHR in pediatric patients. Frontiers Biosci 2010; 15: 913-33.

10. Helsinki, Finland, June 1964, and amended by the $29^{\text {th }}$ WMA General Assembly, Tokio, Japan, October 1975, 35 th WMA General Assembly, Venice, Italy, October 1983, $41^{\text {st }}$ WMA General Assembly, Hong Kong, September 1989, $48^{\text {th }}$ General Assembly, SomersetmWest, Republic of South Africa, October 1996, $52^{\text {nd }}$ WMA General Assembly, Edinburg, Scotland, October 2000, 53 ${ }^{\text {rd }}$ WMA General Assembly, Washington 2002 (note of clarification on paragraph 29 added), $55^{\text {th }}$ WMA General Assembly, Tokyo 2004 (note of clarification on paragraph 30 added), $59^{\text {th }}$ WMA General Assembly, Seoul, October 2008.

11. de Roux N, Misrahi M, Chatelain N, Gross B, Milgrom E. Microsatellites and PCR primers for genetic studies and genomic sequencing of human TSH receptor gene. Mol Cell Endocrinol 1996; 117: 253-6.

12. Bose A, Sharma N, Hemvani N, Chitnis DS. A hospital based prevalence study on thyroid disorders in Malwa region of Central India. Int J Curr Microbiol App Sci 2015; 4: 604-11.

13. Davies TF. The thyroid immunology of the postpartum period. Thyroid 1999; 9: 675-84.

14. Beck-Peccoz P, Persani L, Calebiro D, Bonomi M, Mannavola D, Campi I. Syndromes of hormone resistance in the hypothalamic-pituitary-thyroid axis. Best Pract Res Clin Endocrinol Metab 2006; 20: 529-46.

15. de Roux N, Misrahi M, Brouner R, Houang M, Carel JC, Granier M, Le Bouc Y, Ghinea N, Boumedienne A, Toublanc JE, Milgrom E. Four families with loss of function mutations of the thyrotropin receptor. J Clin Endocrinol Metab 1996; 81: 4229-35.

16. Farid NR, Kascur V, Balazs C. The human thyrotropin receptor is highly mutable: a review of gain-of-function mutations. Eur J Endocrinol 2000; 143: 25-30.

17. Alberti L, Proverbio MC, Costagliola S, Romoli R, Boldrighini B, Vigone $\mathrm{MC}$, Weber $\mathrm{G}$, Chiumello $\mathrm{G}$, BeckPeccoz P, Persani L. Germline mutations of TSH receptor gene as cause of nonautoimmune subclinical hypothyroidism. J Clin Endocrinol Metab 2002; 87: 2549-55.

18. Cangul H, Bas VN, Saglam Y, Kendall M, Barrett TG, Maher ER, Aycan Z. A nonsense thyrotropin receptor gene mutation (R609X) is associated with congenital hypothyroidism and heart defects. J Pediatr Endocrinol Metab 2014; 27: 1101-5

19. Calebiro D, Gelmini G, Cordella D, Bonomi M, Winkler F, Biebermann H, de Marco A, Marelli F, Libri DV, Antonica F, Vigone MC, Cappa M, Mian C, Sartorio A, Beck-Peccoz P, Radetti G, Weber G, Persani L. Frequent TSH receptor genetic alterations with variable signaling impairment in a large series of children with nonautoimmune isolated hyperthyrotropinemia. J Clin Endocrinol Metab 2012; 97: E156-60.

20. Tenenbaum-Rakover Y, Grasberger H, Mamanasiri S, Ringkananont U, Montanelli L, Barkoff MS, Dahood AM, Refetoff S. Loss-of-function mutations in the thyrotropin receptor gene as a major determinant of hyperthyrotropinemia in a consanguineous community. J Clin Endocrinol Metab 2009; 94: 1706-12.

21. Mizuno H, Kanda K, Sugiyama Y, Imamine H, Ito T, Kato I, Togari H, Kamoda T, Onigata K. Longitudinal evaluation of patients with a homozygous $\mathrm{R} 450 \mathrm{H}$ mutation of the TSH receptor gene. Horm Res 2009; 71: 318-23.

\section{Address for correspondence:}

\section{Prof. Dhananjay S. Chitnis}

Department of Microbiology, Immunology and Molecular Biology

Choithram Hospital and Research Centre

Manikbagh Road, Indore, Madhya Pradesh, India

Phone: +91 731 2362491-99, +919302124512

Fax: +91 7312470068

E-mail: ds_chitnis@rediffmail.com 